This is the accepted version of the article entitled:

\title{
Development and Validation of the Spanish Work-Family Conflict Scale (SP- WFCS): Evidence from two independent samples in Argentina
}

The final publication is available at link.springer.com

\section{Lucas Pujol-Cols}

Consejo Nacional de Investigaciones Científicas y Técnicas (CONICET), Argentina, and Universidad Católica del Maule, Chile.

How to cite: Pujol-Cols, L. (2019). Development and Validation of the Spanish Work-Family Conflict Scale (SP-WFCS): Evidence from two independent samples in Argentina. Current Psychology. Advance online publication.

https://doi.org/10.1007/s12144-019-00544-y 


\title{
Development and Validation of the Spanish Work-Family Conflict Scale (SP- WFCS): Evidence from two independent samples in Argentina
}

\begin{abstract}
Research on work-family conflict has increased dramatically in recent years. In this study, we developed a Spanish version of the Work-Family Conflict Scale (Carlson, Kacmar and Williams 2000) and examined its reliability, dimensionality, factor invariance, gender invariance, convergent validity, discriminant validity, and empirical validity. To this end, we analyzed data collected from two independent samples of Argentinian employees $(N$ $=618)$. The results from the confirmatory factor analysis (CFA) revealed that the Spanish Work-Family Conflict Scale (SP-WFCS) displayed a six-dimensional factor structure $(\mathrm{CFI} \geq .96, \mathrm{TLI}=.96, \mathrm{RMSEA}=.06)$. Furthermore, each dimension showed satisfactory levels of internal consistency ( $\alpha$ estimates ranged from .80 to .92), convergent validity (AVE estimates ranged from .59 to .80 , and CR estimates ranged from .81 to .92) and discriminant validity (AVE values $\geq$ shared variance estimates). Moreover, the results from the multi-group confirmatory factor analyses indicated that the six-dimensional model of the SP-WFCS was statistically invariant across samples and gender. Finally, most work-family conflict dimensions displayed significant correlations with three antecedents (i.e., quantitative demands, emotional demands, and core self-evaluations) and two outcomes (i.e., affective job satisfaction and burnout). Taken together, the results provided support to the validity of the SP-WFCS in Argentina, suggesting that it may be a reliable and valid instrument to measure work-family conflict in Spanish-speaking countries. Limitations to the study and opportunities for future research are discussed in this article.
\end{abstract}

Keywords: work-family conflict, job demands, personality, job satisfaction, burnout, validation. 


\section{INTRODUCTION}

The labor market has experienced profound transformations worldwide in the last few decades. Indeed, increasing technological advances, the appearance of more challenging and demanding jobs, a stronger participation of women in the workforce, and an increase in dual-career couples and single-parent households, to name a few factors, have shaped the patterns and dynamics characterizing employment relationships in recent years (Michel, Kotrba, Mitchelson, Clark, and Baltes 2011; Perry-Jenkins and Wadsworth, 2017). In particular, these changes have contributed to fade the boundaries between work and personal life, thus increasing the likelihood of interference between both domains (Amstad, Meier, Fasel, Elfering, and Semmer 2011; Nohe, Meier, Sonntag, and Michel, 2015; Shaffer, Joplin, and Hsu 2011; Vieira, Lopez, and Matos 2014; Zhang and Liu 2011). In this context, individuals are more prompted to experience work-family conflict, that is to say "a form of interrole conflict in which the demands of functioning in the two domains of work and family are incompatible in some respect" (Matthews, Kath, and Barnes-Farrell 2010, p. 76), as participation in one role makes participation in the other role more difficult.

As a result of the aforementioned processes, many organizations around the world have started to place the management of work-family conflict at the core of their human resource policies and strategies, in an attempt to improve well-being levels and effectiveness in the workplace (Rodriguez and Dabos 2017; Rodriguez, Dabos and Rivero 2018). Research on work-family conflict has also increased dramatically in the last few decades (Vieira et al. 2014). Indeed, numerous studies have demonstrated that the extent to which employees experience work-family conflict is associated with several negative individual and organizational outcomes (see Zhang and Liu 2011 for a review), such as job dissatisfaction (e.g., Kreiner 2006; Shockley, and Singla 2011), exhaustion (e.g., 
Berkman, Buxton, Ertel and Okechukwu 2010), burnout (e.g., Haines, Harvey, Durand, and Marchand 2013), life dissatisfaction (e.g., Zhang, Griffeth, and Fried 2012), health symptoms (e.g., O’Donnell, Berkman, Kelly, Hammer, Marden, and Buxton 2019; Peeters, de Jonge, Janssen, and van der Linden 2004), loss of well-being (e.g., Burke and Greenglass 1999; Frone, Russell and Cooper 1997), turnover (e.g., Post, DiTomaso, Farris and Cordero 2009; Shaffer, Harrison, Gilley, and Luk 2001), counterproductive work behavior (e.g., Germeys and De Gieter 2017), and absenteeism (e.g., Goff, Mount and Jamison 1990).

Work-family conflict has been assessed in a variety of ways. As discussed in Carlson, Kacmar and Williams (2000), it has traditionally been examined unidirectionally, as the majority of prior studies have focused on the type of conflict that arises when work interferes with family. However, as Carlson et al. (2000) argued, consideration of different forms and directions of work-family conflict is fundamental to fully understand the complex dynamics and interactions between both domains. On the one hand, work-family conflict can be studied in two directions, namely, work interference with family (WIF) and family interference with work (FIW) (Frone 2003). On the other hand, work-family conflict can also be examined in three forms, namely, time-based conflict, strain-based conflict, and behavior-based conflict (Greenhaus and Beutell 1985). First, time-based conflict arises when time spent in one role makes it difficult to devote time to another role (e.g., not being able to attend an important business meeting because of a family issue). Second, strain-based conflict occurs when the strain experienced by the individual in one role interferes with his or her participation in another role (e.g., feeling emotionally drained after a long day at work may reduce one's ability to cope with family demands). Finally, behavior-based conflict happens when the behavior that is required to be effective in one role is incompatible with the behavior that 
is expected in another role (e.g., being strict may be useful for a teacher in the classroom, but being too strict at home may lead to conflicts with his or her family).

Netemeyer et al. (1996)' 10-item scale is perhaps one of the most commonly used measures to assess work-family conflict. Similarly, the SWING (Survey Work-Home Interaction - NijmeGen; Geurts, Taris, Kompier, Dikkers, Van Hooff, and Kinnunen 2005) has been used in many studies across several countries (e.g., Marais, Mostert, Geurts, \& Taris, 2009; Romeo, Berger, Yepes-Baldó, and Ramos, 2014; Shimada, Shimazu, Geurts, and Kawakami, 2019). Although both instruments have been subjected to thorough development and validation, none of them does fully capture the three forms of work-family conflict suggested by Greenhaus and Beutell (1985), particularly the behavioral dimension (see Matthews et al. 2010). Moreover, both measures assess the two directions of work-family conflict (i.e., WIF and FIW) in a unidimensional way. In this regard, Netemeyer et al. (1996) argued that unidimensional scales are "not as useful as scales that use a multidimensional approach to the measurement of WFC and FWC (family-to-work conflict)" (p. 408).

With the aim of overcoming some of the limitations that characterized the majority of the existing scales on work-family conflict, Carlson et al. (2000) developed an 18-item, multidimensional measure of work-family conflict, named Work-Family Conflict Scale (WFCS). This measure was designed to assess six possible combinations of work-family conflict, namely, time-based WIF, time-based FIW, strain-based WIF, strain-based FIW, behavior-based WIF, and behavior-based FIW. By using five independent samples, Carlson et al. (2000) demonstrated that the WFCS displayed satisfactory results in various psychometric tests, including internal consistency $(.78 \leq \alpha \leq .87$ ), factor structure (fit statistics for the six-dimensional model: $\mathrm{CFI}=.95$, RMSEA $=.06$ ), factor invariance $(\Delta \mathrm{CFI} \leq .01$ across models), gender invariance $(\Delta \mathrm{CFI} \leq .01$ across models), convergent 
validity (factor loadings $\geq .69$ ), discriminant validity (factor covariances ranged from .24 to .83 , but only two of them were above .60), and empirical validity (statistically significant correlations with specific antecedents and outcomes of work-family conflict).

So far, the WFCS has been used in numerous studies in the past (e.g., Allen and Armstrong 2006; Bruck, Allen, and Spector 2002; van Steenbergen, Ellemers, and Mooijaart 2007; Witt and Carlson 2006). However, and though it has been suggested that the WFCS constitutes one of the most reliable and valid instruments to assess work-family conflict, the empirical evidence regarding its psychometric properties across countries is still limited, as only a few studies have conducted a thorough examination of its crosscultural validity outside the United States (e.g., Mortazavi, Pedhiwala, Shafiro and Hammer 2009; Watai, Nishikido, and Murashima 2006). To provide an example, Vieira et al. (2014) recently demonstrated that the WFCS displayed satisfactory psychometric properties in Portugal, in terms of internal consistency $(.77 \leq \alpha \leq .90)$, factor structure (fit statistics for the six-dimensional model: $\mathrm{CFI}=.97, \mathrm{RMSEA}=.05)$, gender invariance $(\Delta \mathrm{CFI} \leq .01$ across models), convergent validity $(.54 \leq \mathrm{AVE} \leq .76)$, and discriminant validity (factor covariances ranged from .19 to .61), which was consistent with Carlson et al. (2000)'s validation study.

As discussed in Zhang et al. (2012), research on work-family conflict has primarily been conducted in Anglo-Saxon settings. In this regard, and though "the nature of workfamily interface may vary along cultural boundaries" (p. 697; also see Ford, Heinen, and Langkamer 2007; Spector, Allen, Poelmans, Lapierre, Cooper, O’Driscoll et al. 2007), to our knowledge, no previous study has conducted an intensive development and validation of a Spanish version of the WFCS. Thus, the purpose of this study is to develop and to validate the Spanish Work-Family Conflict Scale (SP-WFCS). More specifically, we examine its psychometric properties in terms of internal consistency, factor structure, 
factor invariance, gender invariance, convergent validity, discriminant validity, and empirical validity, by using data collected from two independent samples of employees in Argentina $(N=618)$.

To assess the empirical validity of the SP-WFCS, in this study, we examine the correlations of the six dimensions with specific antecedents and outcomes from the nomological network. Although, so far, researchers have considered a number of different variables as possible antecedents of work-family conflict (Byron 2005), as argued by Shaffer et al. (2011), "in general, the work-family literature has been atheoretical, mainly because of the complexity and multiplicity of the work-family interface" (p. 230). Indeed, Shaffer et al. (2011) showed that nearly half of the studies they reviewed did not draw upon any theory to examine hypothesized relationships. In our study, however, we adopt an interactionist approach to the study of the antecedents of work-family conflict, as past literature has suggested that individuals' experiences in the workplace are the result of both dispositional and situational factors (see the concept of interactionism in Funder 2008; also see Funder, Guillaume, Kumagai, Kawamoto, and Sato 2012). From this perspective, as people's attitudes and behavior are shaped by the characteristics of each situation they encounter (i.e., situational effects), they also maintain their individual differences (i.e., dispositional effects). The adoption of an interactionist approach, it follows, is fundamental to better understand the dynamics underlying individuals' experiences of work-family conflict.

On the one hand, dispositional research has consistently demonstrated that dispositions significantly affect the way employees perceive and react to the characteristics of their job (e.g., Judge et al. 2000; Kammeyer-Mueller, Judge, and Scott 2009; Pujol-Cols 2019; Srivastava, Locke, Judge, and Adams 2010; Wu and Griffin, 2012). Drawing on this evidence, in this study, we select one dispositional antecedent, 
namely, core self-evaluations (CSEs), which consist of a broad, higher-order personality trait that reflects individuals' beliefs regarding their worthiness, competence, and capabilities (Judge, Erez, Bono, and Thoresen 2003). Thus, we expect those individuals with more positive CSEs to report lower levels of work-family conflict, as they are more likely to perceive and react to this work-related factor in a more positive way (Haines III et al. 2013).

Beyond the effects of dispositional antecedents, numerous studies have consistently shown that situational factors may also contribute to explain individuals' experiences in the workplace (Dierdorff and Morgeson 2013; Humphrey, Nahrgang, and Morgeson 2007). In this regard, the scarcity theory, the effort-recovery theory, and the role theory are, perhaps, the most frequently used theories in the work-family conflict research (see Shaffer et al., 2011 for a review). Although these three theories have their own merits when it comes to explaining work-family interactions, in this study, we follow the effortrecovery theory (see Meijman and Mulder 1998) as it effectively captures the nature of the effects of job demands on work-family conflict. From this perspective, those individuals who are required to spend a considerable amount of energy on their job, without having sufficient opportunities for recovery, may face higher psychological, physiological, and social costs, including a negative spillover to the family domain (Geurts, Kompier, Roxburgh and Houtman 2003). Drawing on this evidence, in this study, we select two situational antecedents, namely, quantitative demands and emotional demands, which have been argued to significantly explain individuals' perceptions of work-family conflict in the past literature (Byron 2005). Thus, since previous metaanalytic findings have demonstrated that work characteristics such as work overload or emotional demands (i.e., those aspects of the job that require a sustained emotional effort) are also associated with work-family conflict (e.g., Michel et al. 2011), we expect 
perceptions of higher quantitative and emotional demands to be related to higher levels of work-family conflict.

In regards to the outcomes of work-family conflict, in this study, we follow Amstad et al. (2011) and measure participants' levels of affective job satisfaction and burnout. While affective job satisfaction represents an individual's affective response towards his or her job as a whole (see Pujol-Cols and Dabos 2019), burnout reflects a prolonged response to chronic emotional and interpersonal stressors on the job that is characterized by high levels of emotional exhaustion and depersonalization, and low levels of personal accomplishment. Thus, we expect increasing levels of work-family conflict to be associated with lower levels of job satisfaction and higher levels of burnout.

As argued by Matthews et al. (2010) "the measure developed by Carlson et al. (2000) is perhaps the best example of a measure intended to account for the three bidirectional types of pressures [...] [It is] one of the most theoretically and psychometrically sound measures of work-family conflict available to researchers today" (p. 76). Therefore, instead of developing an entirely new, ad-hoc measure, we decided to translate the WFCS, as this instrument has already been subjected to a thorough development and validation. Thus, we believe that the SP-WFCS may be useful to encourage future research on the factors, interactions, and dynamics involved in workfamily relationships in Iberoamerican settings. Moreover, by developing and validating the SP-WFCS in the Argentinian context, we respond to Vieira et al.'s (2014) recent calls for testing the validity of the WFCS in different countries and cultures, particularly outside the United States. Furthermore, since the WFCS is a standardized, generic measure that has been widely used in numerous studies, the development of a Spanish version of this instrument may not only be useful to promote future research on workfamily conflict in Spanish-speaking countries, but also to compare findings across 
different organizational, occupational, and cultural settings (Buss 2009; Hogan 2009; Reiss 2008). Finally, this study contributes to a broader literature on work-family conflict by providing evidence of the cross-cultural validity of the original WFCS.

\section{METHOD}

\subsection{Translation procedure}

Following guidelines from the International Test Commission (2017), we performed forward and backward translation procedures in five stages (see Brislin 1980). This approach has been used in numerous validation studies (e.g., Pezirkianidis, Stalikas, Lakioti, and Yotsidi 2019; Vieira et al. 2014). The main purpose of these procedures was to develop a linguistically equivalent and culturally appropriate Spanish version of the WFCS (see Hambleton, Merenda, and Spielberger 2006; Muñiz, Elosua, and Hambleton 2013). First, two researchers, who were native Spanish speakers and proficient in English, independently translated the English version of the WFCS into Spanish (i.e., independent forward translation). Second, both researchers, along with the author of this article, compared these versions of the WFCS and agreed on the final forward translation of the instrument (i.e., forward translation verification - committee approach). Third, other two researchers independently translated the SP-WFCS back into English (i.e., independent backward translation). Fourth, these two researchers, along with the author of this article, compared the back-translations and reached consensus on the final back-translated version of the questionnaire (i.e., backward translation verification - committee approach). Finally, a bilingual expert, who had postdoctoral training in linguistics and was well published in cross-cultural research, compared the translations and backtranslations of the instrument with the original WFCS (i.e., final verification by an expert). Based on the expert's suggestions, we reached consensus on the final version of the SP-WFCS (see Acknowledgements). 


\subsection{Participants}

We collected data from two independent samples of Argentinian employees, who worked in different organizations in a metropolitan area of Buenos Aires, Argentina. As a preliminary step, we used Daniel Soper's (2019) software to calculate the minimum sample size required for conducting a confirmatory factor analysis with structural equations, given the anticipated effect size, the number of observed and latent variables in the model, and the desired statistical power and probability levels. The results indicated that the minimum required sample size to test the model fit in each sample was 200 individuals.

Sample 1. Participants were a non-random sample of 215 employees, aged between 21 and $69(M=40.26, S D=9.60)$ years old. The majority of the respondents were male (58.14\%). Only a small percentage of the participants were not married (or living with a life partner) and had no children (31.16\%). The respondents' average tenure in the current organization ranged between 1 and $39(M=10.75, S D=8.89)$ years. Regarding the participants' level of education, $1.40 \%$ finished primary school, $17.67 \%$ finished high school, and $80.94 \%$ had a College degree. All of the participants worked, at least, 20 hours a week and the majority of them $(80 \%)$ had full-time jobs.

Sample 2. It consisted of 403 teachers aged between 22 and $68(M=41.63, S D=$ 10.84) years old. About $21.84 \%$ of the teachers worked in primary schools, $31.51 \%$ worked in secondary schools, and $46.65 \%$ worked in universities. The majority of the participants were female $(81.89 \%)$. The average tenure of the respondents ranged between 1 and $43(M=14.65, S D=10.41)$ years. Only a small percentage of the participants were not married (or living with a life partner) and had no children $(20.84 \%)$. Regarding the respondents' educational level, 59.55\% had a College degree, $27.30 \%$ had 
a Master's degree, and $13.15 \%$ had a Ph.D. All of the participants worked, at least, 20 hours a week and the majority of them $(83.62 \%)$ had full-time jobs.

\subsection{Data collection procedure}

Data were collected between September and December 2018 and between February and July 2019 in samples 1 and 2, respectively, in a metropolitan area of Buenos Aires. It is worth mentioning that these two samples were selected as they were both likely to be exposed to moderate to high levels of quantitative and emotional demands, and, as a result, to increasing work-family conflict. Following approval of the study by the National Scientific and Technical Research Council, Argentina (record \#270318), the potential participants were contacted through a networking approach, which is also known as 'snowball sampling' (see Lazzaro-Salazar 2018 for an excellent discussion on this matter), which consists of contacting one participant or groups of participants and asking them to recruit another potential participant or group of participants. This sampling strategy represents a standard procedure in organizational behavior/psychology research and offers many benefits including, for instance, higher response rates (Baltar and Brunet 2012). Indeed, this approach tends to increase participants' willingness and motivation to participate in a study as it adheres to the principle of the participatory paradigm (see Hugman, Pittaway, and Bartolomei 2011).

Regarding sample 1, we initially recruited a group of individuals who were enrolled in a part-time Master of Business Administration (MBA) program and occupied middle managerial positions in medium-sized organizations from different industries. These individuals were contacted by email through the coordinator of the MBA program and were asked to fill out an online survey. They were also asked to share the online invitation with at least one of their colleagues who might be interested in participating in the study. Eligible participants had to be currently employed and worked, at least, 20 hours a week. 
Regarding sample 2, we first contacted the maximum academic authorities (i.e., the Deans) of two medium-sized universities, as well as the headmasters of several primary and secondary schools, and asked them to send online invitations to their respective faculties. All of the potential respondents were also asked to share the invitations with their colleagues. Eligible participants had to be currently employed and worked, at least, 20 hours a week.

In both samples, authorities, on the one hand, and highly motivated participants, on the other hand, acted as gatekeepers, who were willing to recruit participants within their teams and networks (see Lazzaro-Salazar 2018). Online invitations included a description of the purposes of the study and a consent form. Access to the online survey was only granted if consent to participate in the study was given by clicking on the 'yes' option of the consent form. Responses to the survey were anonymous.

\subsection{Measures and instruments}

\section{Work-family conflict}

We measured the six dimensions of work-family conflict suggested in Greenhaus and Beutell (1985) using the Work-Family Conflict Scale (Carlson et al. 2000). It consisted of 18 items (see Appendix) with a response scale ranging from 1 (totally disagree) to 5 (totally agree).

\section{Antecedents of work-family conflict}

Core Self-Evaluations (CSEs). Participants' CSEs were examined with the 12-item Core Self-Evaluations Scale (CSES; Judge, Erez, Bono, and Thoresen 2003). Example items included "I complete tasks successfully" and "Sometimes, I do not feel in control of my work" (reverse scored). Responses for each item were anchored in a 5-point Likert scale ranging from 1 (totally disagree) to 5 (totally agree). It is worth noting that the CSES has shown satisfactory psychometric properties in previous studies conducted in 
Argentinian settings (e.g., Pujol-Cols and Dabos 2017; Pujol-Cols 2019; Pujol-Cols and Dabos 2019). Moreover, numerous studies have demonstrated that the CSES exhibits a unidimensional structure (e.g., $.87 \leq \mathrm{CFI} \leq .95, .88 \leq \mathrm{GFI} \leq .94, .06 \leq \mathrm{RMSEA} \leq .10$; for more detailed information regarding the psychometric properties of the CSES, please see Judge et al. 2003). The reliability for this scale was $\alpha=.76$ in sample 1 and $\alpha=.81$ in sample 2.

Quantitative demands. Work-related quantitative demands, which reflect the volume and intensity of workload, were assessed using three items (e.g., "do you have enough time to do your job effectively?") taken from the Spanish Copsoq-Istas Psychosocial Risk Questionnaire (Moncada et al 2004). The validity of this scale has been demonstrated in previous studies conducted in Argentinian settings (e.g., Pujol-Cols and Arraigada 2017; Pujol-Cols and Lazzaro-Salazar 2018; Pujol-Cols 2019). Responses ranged from 1 (never/ to a very small extent) to 5 (always/ to a very great extent). The reliabilities of the scale were $\alpha=.73$ in sample 1 , and $\alpha=.73$ in sample 2 .

Emotional demands. Work-related emotional demands, which reflect those aspects of the job that require a sustained emotional effort, were measured with two items (e.g., “do you face emotional situations at work?") taken from the Spanish Copsoq-Istas Psychosocial Risk Questionnaire (Moncada et al 2004; also see Pujol-Cols and Arraigada 2017) and three items (e.g., "do you encounter situations on board that personally affect you?") based on the scale developed by Bakker, Demerouti, and Verbeke (2004). Responses ranged from 1 (never/ to a very small extent) to 5 (always/ to a very great extent). The reliabilities of the scale were $\alpha=.77$ in sample 1 and $\alpha=.78$ in sample 2 .

\section{Outcomes of work-family conflict}

Job satisfaction. Affective job satisfaction was measured only in sample 1 using the Brief Index of Affective Job Satisfaction (BIAJS; Thompson and Phua 2012). This scale 
has been validated in previous studies conducted in Argentinian organizational settings (e.g., Pujol-Cols and Dabos 2017; Pujol-Cols and Dabos 2019). It consisted of four items and a 5-point Likert scale ranging from 1 (totally disagree) to 5 (totally agree). An example item is "I find real enjoyment in my job". The reliability for this scale was $\alpha=$ .90 .

Burnout. Participants' level of burnout was assessed only in sample 2 using the Maslach Burnout Inventory-Educators Survey (MBI-ES; Maslach, Jackson, and Leiter 1996). The MBI-ES comprises 22 items grouped in three dimensions: emotional exhaustion (e.g., 'I feel emotionally drained from my work'), depersonalization (e.g., 'I feel I treat some students as if they were impersonal objects'), and personal accomplishment (e.g., 'I have accomplished many worthwhile things in this job'). Responses to the MBI-ES were anchored in a 5-point Likert scale ranging from 1 (never) to 5 (every day). Lower scores on personal accomplishment and higher scores on depersonalization and emotional exhaustion suggested higher levels of burnout. The reliabilities were $\alpha=.86$ for the emotional exhaustion sub-scale, $\alpha=.75$ for the depersonalization sub-scale, and $\alpha=.81$ for the personal accomplishment sub-scale.

\subsection{Validation procedure}

The psychometric properties of the SP-WFCS were examined in terms of internal consistency, factor structure, factor invariance, gender invariance, convergent validity, discriminant validity, and empirical validity. First, we assessed the factor structure of the scale by conducting a confirmatory factor analysis (CFA) with structural equations in Amos 22 (Arbuckle 2014; see Bollen 1989). The estimation method was maximum likelihood. Next, we performed a multi-group structural equation modeling test to verify if the factor structure was invariant across samples. Further, we also conducted a multigroup structural equation analysis to test if the factor structure held across gender. Second, 
we examined the reliability of the scale by calculating Cronbach's alpha coefficients (see Nunnally 1978). Third, we followed the procedure in Fornell and Larcker (1981) and examined the convergent validity of the SP-WFCS by calculating the average variance extracted (AVE) and composite reliability (CR) for each work-family conflict dimension. As suggested by Hair et al. (2010), AVE values higher than .50, as well as CR estimates higher than .70 , indicate a satisfactory convergent validity. Fourth, we compared each dimension's AVE estimates with their respective shared variance estimates to assess the discriminant validity of the SP-WFCS. Finally, we examined the empirical validity of the scale by analyzing the correlations of each dimension with specific antecedents (i.e., core self-evaluations, quantitative demands, and emotional demands) and outcomes (i.e., affective job satisfaction and burnout) from the nomological network.

\section{RESULTS}

\subsection{Common method bias}

Following Podsakoff et al. (2003), since all of the variables included in this study were measured at the same time, there is a potential for common method bias. This issue was addressed by conducting Harman's one factor test, in which all the observed variables in the study were simultaneously entered into an exploratory factor analysis. Results revealed that the one single factor accounted only for $23.75 \%$ and $23.83 \%$ of the variance in samples 1 and 2, respectively, suggesting that the common-method bias did not affect our data or our results.

\subsection{Dimensionality}

We used confirmatory factor analysis (CFA) to assess the factor structure of the SPWFCS $(\mathrm{KMO}=.88$ in sample 1 and .89 in sample 2 , Bartlett's test of sphericity was statistically significant in both samples). Following Carlson et al. (2000), we tested four competing models in Amos 22 (Arbuckle 2014; see Table 1). First, we examined a six- 
dimensional model (see Figure 1), where each dimension of work-family conflict (i.e., time-based WIF, time-based FIW, strain-based WIF, strain-based FIW, behavior-based WIF, behavior-based FIW) was entered separately as a latent variable. Second, we tested a three-dimensional model, which included the three forms of work-family conflict (i.e., time, strain, and behavior) as latent variables. Third, we estimated a two-factor model, where the two directions of work-family conflict (i.e., work interference with family and family interference with work) were entered as latent variables. Finally, we examined a unidimensional model, where all of the 18 items were hypothesized to load into a single work-family conflict latent construct. In each model, we allowed the factors to correlate freely.

To compare the four models, we estimated and evaluated different goodness of fit indices, including $\chi^{2}$ (Chi-square), RMSEA (Root Mean Square Error of Approximation), CFI (Comparative Fit Index), and TLI (Tucker-Lewis Index). According to $\mathrm{Hu}$ and Bentler (1999), CFI and TLI values greater than .90 and RMSEA values smaller than .08 indicate a satisfactory fit (also see Byrne 2001). As shown in Table 1, the six-factor model exhibited the best fit to the data across the two samples. More specifically, the fit indices were satisfactory not only in sample $1-\chi^{2}(215,120)=218.62, p<.01$, CFI $=.96$, TLI $=$ .96, RMSEA $=.06-$ but also in sample $2-\chi^{2}(215,120)=293.93, p<.01$, CFI $=.97$, TLI $=.96$, RMSEA $=.06-$ which provided empirical support to the six-factor structure of the SP-WFCS. Figure 1 displays the standardized factor loadings for the six-dimensional model. Finally, it should be noted that, although the chi-square test was statistically significant in both samples, numerous studies have recognized that this measure is highly sensitive to sample size (see Kline 2010). 


\section{INSERT FIGURE 1 ABOUT HERE}

Consistently with Carlson et al.' (2000) procedure, we tested whether our samples were confounded by including a small percentage of employees who were not married (or living with a life partner) and had no children. In both cases, the results for the hypothesized model drawn on the full and more constrained sample indicated no differences between samples. The results of the difference tests were $\Delta \chi 2(51)=15.69, p$ $=1.00, \Delta \mathrm{CFI}=.00$, and $\Delta \chi 2(51)=5.45, p=1.00, \Delta \mathrm{CFI}=.00$ for samples 1 and 2 , respectively. Thus, and consistently with Carlson et al. (2000), we reported the results for the full samples.

\subsection{Internal consistency}

We estimated the internal consistency of each of the six dimensions of the SPWFCS by calculating Cronbach's alpha coefficient. As shown in Table 2, the reliabilities were similar across the two samples, with internal consistency estimates ranging from .80 to .92 in sample 1 and from .84 to .91 in sample 2. Cronbach's alpha coefficients above the conventional level of acceptance of .70 indicated an appropriate internal consistency (DeVellis 2012; Nunnally 1978). 


\subsection{Convergent validity}

We examined the convergent validity of the SP-WFCS, that is to say, the extent to which the indicators of each latent factor share a high proportion of variance, by calculating the average variance extracted (AVE) for each of the six WFC dimensions. Following Fornell and Larcker (1981), the AVE estimate measures the amount of variance that is captured by a construct in relation to the amount of variance due to measurement error. As suggested by Hair et al. (2010), AVE values higher than .50 indicate a satisfactory convergent validity. As shown in Table 3, AVE ranged from .59 to .80 in sample 1 and from .66 to .77 in sample 2 . We also examined the convergent validity of the SP-WFCS by calculating each factor's CR. Following Hair et al. (2010), CR values higher than .70 indicate a satisfactory convergent validity. As reported in Table 3, CRs ranged from .81 to .92 in sample 1 and from .85 to .91 in sample 2 . Taken together, these findings indicated that the SP-WFCS exhibited an adequate convergent validity across the two independent samples.

\section{INSERT TABLE 3 ABOUT HERE}

\subsection{Discriminant validity}

To assess the discriminant validity of the SP-WFCS, we compared each factor's AVE with its shared variance estimates (see Hubley 2014). The shared variance between two factors represents the extent to which the variation of both factors tends to overlap and it is measured by calculating the square of the correlation coefficient. Discriminant validity exists if each factor's AVE is greater than its squared correlations (i.e., shared variance) with other factors (see Fornell and Larcker 1981). As shown in Table 4, AVE 
estimates were, overall, greater than shared variance estimates. Thus, these findings demonstrated the discriminant validity of the SP-WFCS.

\section{INSERT TABLE 4 ABOUT HERE}

\subsection{Factor structure tests}

To examine whether the dimensionality of the six-factor model held across samples, we conducted a multi-group confirmatory factor analysis with each data set representing an independent group (Hirschfeld and Von Brachel 2014; Kline 2010). As argued by Carlson et al. (2000), this procedure is useful because "it allows the factor loadings, correlations, and error variances to be held invariant individually or in combination" (p. 263; also see Bagozzi and Yi 1988). Consistently with the original validation study in Carlson et al. (2000), we estimated and compared four two-group models (see Table 5). In the first model, we specified the same measurement model across both groups and allowed the factor loadings, correlations, and error variances to vary freely within each sample. In the second model, we allowed the factor correlations and error variances to vary, but the factor loadings were held invariant (i.e., the factor loadings were required to be equivalent across groups). In the third model, we required the factor loadings and correlations to be equivalent but allowed the error variances to vary across the data sets. Finally, in the fourth model, we required the factor loadings, factor correlations, and error variances for both data sets to be equal (i.e., the error variances were required to be equivalent across groups).

The results of the factor invariance tests are reported in Table 5. As this table shows, the fit statistics for the baseline model were satisfactory $-\chi^{2}(618,240)=512.64, p<.01$, $\mathrm{CFI}=.97, \mathrm{TLI}=.96, \mathrm{RMSEA}=.04-$ which suggested configural invariance (i.e., 
participants from both samples seemed to conceptualize the constructs in the same way; see Kline 2010). Moreover, the unconstrained model was not significantly different from the model with the factor loadings held invariant (i.e., model 2), suggesting metric invariance. The baseline model, however, was found to be significantly different from the model with the factor correlations held invariant $(p<.05)$ and from the model with the factor loadings, factor correlations, and error variances held invariant $(p<.01)$. In this regard, Kline (2010) argued that fit statistics, such as CFI, should also be interpreted when examining factor invariance, as the chi-square difference test is highly sensitive to sample size (also see Williams, Bozdogan, and Aiman-Smith 1996). Indeed, Kline (2010) warned us that "the chi-square difference test $[\ldots]$ could be statistically significant even though the absolute differences in parameter estimates are of trivial magnitude" (p. 400). As argued by Cheung and Rensvold (2002), changes in CFI values less than or equal to .01 indicate that the null hypothesis of invariance should not be rejected. Moreover, in their validation study, Carlson et al. (2000) pointed out that "invariant error variances are considered the least important in testing measurement property invariance across groups" (p. 265).

Thus, metric invariance was also examined by comparing the CFI estimates of models 1 and 2. CFI differences smaller than .01 indicated metric invariance (Kline 2010). Moreover, CFI differences between models 2 and 3 and between models 3 and 4 smaller than .01 provided further evidence of invariance (Kline 2010). Finally, it should be noted that the fit statistics for the most constrained model (i.e., model 4) were satisfactory (see Table 5). Taken together, these findings indicated that the sixdimensional model can be generalized across the two data sets, thus providing evidence of measurement invariance (Cheung and Rensvold 2002). 


\section{INSERT TABLE 5 ABOUT HERE}

\subsection{Gender differences}

To analyze whether the factor structure of the six-dimensional model held across gender, we performed a two-group measurement procedure in Amos 22 (Arbuckle 2014). In order to increase the statistical power of our models, as well as to balance the sample size of both groups, we decided to combine both samples for the analysis $(N=618)$. Consistently with Carlson et al. (2000) and Vieira et al.'s (2014) validation studies, we tested four two-group models. In the first model, we specified the same measurement model across both groups and allowed the factor loadings, correlations, and error variances to vary freely within each sample. In the second model, we allowed the factor correlations and error variances to vary, but the factor loadings were held invariant. In the third model, we required the factor loadings and correlations to be equivalent but allowed the error variances to vary across the datasets. Finally, in the fourth model, we required the factor loadings, factor correlations, and error variances for both data sets to be equal.

As shown in Table 6, the results revealed that the fit statistics for the baseline model were satisfactory, $\chi^{2}(618,240)=488.47, p<.01, \mathrm{CFI}=.97, \mathrm{TLI}=.96, \mathrm{RMSEA}=.04$. Moreover, the unconstrained model was not significantly different from the model with the factor loadings held invariant. The baseline model, however, was found to be significantly different from the model with the factor correlations held invariant $(p<.01)$ and from the model with the factor loadings, factor correlations, and error variances held invariant $(p<.01)$. Since, as discussed earlier in this article, chi-square difference tests are sensitive to sample size (Kline 2010), we followed the recommendations by Cheung and Rensvold (2002) and analyzed the changes in fit statistics, such as CFI, to further 
examine gender invariance. As shown in Table 6, CFI differences were lower than .01 in all cases, which demonstrated that the six-dimensional WFC model mapped well across gender with respect to their factor loadings, factor correlations, and error variances.

\section{INSERT TABLE 6 ABOUT HERE}

\subsection{Empirical validity}

To assess the empirical validity of the SP-WFCS, we examined the correlations of the six dimensions with specific antecedents and outcomes from the nomological network (see Table 7). In regards to the antecedents of work-family conflict, previous studies have suggested that work-family conflict may be affected by both dispositional and situational factors. As shown in Table 7, the results revealed that CSEs $(-.24 \leq \mathrm{r} \leq-.40$ in sample 1 and $-.23 \leq \mathrm{r} \leq-.37$ in sample 2$)$, quantitative demands $(.11 \leq \mathrm{r} \leq .38$ in sample 1 and .17 $\leq \mathrm{r} \leq .44$ in sample 2$)$, and emotional demands $(.10 \leq \mathrm{r} \leq .41$ in sample 1 and $.26 \leq \mathrm{r} \leq .64$ in sample 2) were significantly correlated with the six dimensions of work-family conflict. On the one hand, the findings showed that those individuals with more positive CSEs tended to experience lower work-family conflict (i.e., dispositional source of workfamily conflict). Moreover, those employees facing increasing quantitative demands and/or emotional demands at work were more likely to experience higher work-family conflict (i.e., situational sources of work-family conflict). It should also be noted that the correlations between quantitative and emotional demands, and the three dimensions reflecting work-to-family interferences were stronger than the correlations between quantitative and emotional demands, and those dimensions reflecting family-to-work interferences. 
Regarding the outcomes of work-family conflict, the results revealed that the six dimensions significantly predicted affective job satisfaction $(-.11 \leq \mathrm{r} \leq-.23)$, suggesting that those individuals facing higher work-family conflict tended to experience a less positive attitude towards their job as a whole. Moreover, the six dimensions of workfamily conflict displayed positive and statistically significant correlations with emotional exhaustion $(.28 \leq \mathrm{r} \leq .68)$ and depersonalization $(.17 \leq \mathrm{r} \leq .33)$, suggesting that those employees experiencing higher work-family conflict were more likely to suffer from emotional exhaustion and/or depersonalization. Finally, only strain-based WIF, strainbased FIW, behavior-based WIF, and behavior-based FIW $(-.11 \leq \mathrm{r} \leq-.19)$ were found to be significantly related to personal accomplishment, indicating that increasing perceptions of work-family conflict were associated with a lower sense of personal accomplishment.

\section{INSERT TABLE 7 ABOUT HERE}

\section{DISCUSSION}

Research on work-family conflict has increased dramatically in recent years, mainly as a result of the profound transformations that have affected employment relationships in the last few decades (Amstad et al. 2011; Byron 2005; Michel et al. 2011; Shaffer et al. 2011). As argued by Matthews et al. (2010), the WFCS (Carlson et al. 2000) "is one of the most theoretically and psychometrically sound measures of work-family conflict available to researchers today" (p. 76), as it effectively accounts for the six types of workfamily conflict suggested in Greenhaus and Beutell (1985), namely, time-based WIF, time-based FIW, strain-based WIF, strain-based FIW, behavior-based WIF, and behavior-based FIW. Although the WFCS has been successfully validated in the United 
States (e.g., Carlson et al. 2000), Japan (e.g., Watai et al. 2006), and Portugal (e.g., Vieira et al. 2014), to date, no previous study has performed an intensive development and validation of a Spanish version of this instrument. The purpose of the present research, then, was to develop a reliable and valid Spanish version of Carlson et al. (2000)'s WFCS.

The results showed that the SP-WFCS displayed satisfactory psychometric properties across the two data sets that were used in this research. On the one hand, the six dimensions of the SP-WFCS showed an acceptable internal consistency, with Cronbach's alpha coefficients ranging from .80 to .92 . Beyond reliability, on the other hand, several pieces of evidence supported the validity of the SP-WFCS. First, our data provided an adequate support to the six-dimensional structure of the WFCS that has been previously suggested in the literature (e.g., Carlson et al. 2000; Vieira et al. 2014). Second, the SP-WFCS showed a satisfactory convergent validity across both samples, with AVE values ranging from .59 to .80 and CR estimates ranging from .81 to .92 . Third, it displayed an acceptable discriminant validity, with AVE estimates above shared variance estimates. Fourth, it was found to be significantly correlated with five focal constructs in organizational behavior/psychology research (i.e., CSEs, quantitative demands, emotional demands, affective job satisfaction, and burnout) across the two independent samples, which provided evidence of the empirical validity of the instrument.

This research has several strengths. Firstly, the psychometric properties of the SPWFCS were examined following a thorough and rigorous validation procedure. Secondly, we also used data collected from two independent samples, thus reducing the potential for sample specific bias. Using multiple samples also allowed us to examine the invariance of the scale across samples (Carlson et al. 2000). Indeed, the results of this study demonstrated that the factor structure of the six-dimensional model of work-family 
conflict was invariant across the two samples. Moreover, the findings also showed that the six-factor structure was invariant across gender.

Taken together, these findings provided support to the reliability and validity of the SP-WFCS in the Argentinian context. Furthermore, since this was the first study to explore the psychometric properties of the SP-WFCS, it also made a significant contribution to the work-family conflict literature by providing evidence of the crosscultural validity of the original WFCS, which, so far, has mostly been validated in the United States. Although we are confident that the SP-WFCS may be a psychometrically sound measure to examine work-family conflict in Spanish-speaking countries, future studies should further examine its reliability and validity in other countries to determine whether the psychometric properties hold across cultural boundaries.

As argued by Zhang et al. (2012), research on work-family conflict has primarily been conducted in Anglo-Saxon settings. However, since "the nature of work-family interface may vary along cultural boundaries" (p. 697; also see Ford et al. 2007; Spector et al. 2007), we believe that future studies should further examine the factors, interactions, and dynamics underlying the work-family interface in Latin America. We are confident that the SP-WFCS may be useful to promote future research on work-family conflict in this context. Moreover, unlike ad hoc scales, which may be too context-specific, the SPWFCS is a standardized, generic measure that has been widely used in organizational behavior/psychology research. Thus, using the SP-WFCS may facilitate the comparison of findings across different organizational settings, industries, and countries.

In addition to the research implications of the SP-WFCS, we believe this instrument might also be used in professional practice. However, when using the SP-WFCS to measure employees' perceptions of work-family conflict in organizational settings, data should be collected in such a way that the participants can be sure that their responses to 
the survey will be held confidential. Otherwise, if employees do not feel they can answer honestly and without fear of retaliation, they either will complete the questionnaire in a socially desirable way or will simply not participate in the study.

Since this study addressed the empirical validity of the SP-WFCS, some practical implications can also be gleaned from these findings. First, our results suggested that CSEs were found to be significantly related to the six dimensions of work-family conflict. These findings have strong implications for personnel selection, as our results indicated that individuals with less positive personality traits seem to be most likely to experience increasing work-family conflict. Second, our results demonstrated that both quantitative and emotional demands were found to be significantly related to most work-family conflict dimensions. In this regard, we believe that organizations should pay close attention to the psychological demands they impose on their employees, as these pressures may lead to interferences between work and personal life and, as a result, to negative effects on individuals' well-being. For instance, organizations could reduce the amount of tasks and responsibilities that employees have to perform outside their working hours (e.g., answering phone calls, replying to e-mails), so that they can take advantage of their spare time to fully recover from the demands of each working day. Finally, managers should also design strategies and policies to reduce work-family conflict, as the results of our study showed that higher levels of work-family interference were related to increasing levels of burnout and lower levels of job satisfaction.

In spite of the strengths and contributions of our study, it also has some limitations that should be acknowledged. First, we only used two samples to test the psychometric properties of the SP-WFCS. Although our samples included adults of different ages and gender, who worked in different organizations, industries, and organizational levels, both samples may have been a little homogeneous in terms of qualification (i.e., the 
respondents in both samples had, on average, high educational levels). Moreover, since both samples included only Argentinian employees, there is still a need for future crosscultural validation of the SP-WFCS in other Spanish-speaking countries (inside and outside Latin America). Second, we used self-report questionnaires to measure all of the constructs included in this study, which may cause common method bias (Podsakoff, MacKenzie, Lee, and Podsakoff 2003). Although the results of Harman's one factor test suggested that the common-method bias did not affect our findings, we believe that future studies should further address this issue by including other independent measures of the constructs of interest. Thus, future research could include objective measures of personality traits (e.g., participants' level of neuroticism could be measured through a clinical diagnosis made by a therapist), job demands (e.g., participants' level of exposure to job demands, such as psychological demands, could be examined by performing a detailed analysis of the job description), and health outcomes (e.g., the presence of physical complaints, such as chronic migraines, could be assessed through a clinical diagnosis made by a physician). Such mixed and transdisciplinary approach to the study of work-family conflict may provide a rich opportunity for advancing our understanding of the mechanisms involved and their relationships in a more holistic and, thus, comprehensive way (see considerations in Pujol-Cols and Lazzaro-Salazar in press). Third, we used cross-sectional data, which prevents us from drawing causal inference. Future research should measure the work-family conflict dimensions, as well as their antecedents and outcomes, at different points of time. Fourth, we only used five constructs (three antecedents and two outcomes) to assess the nomological relationships of the SPWFCS subscales. Future studies using this instrument may provide a better understanding regarding how each dimension of work-family conflict relates to other antecedents (e.g., job flexibility, social support) and outcomes (e.g., turnover intentions, family satisfaction, 
marital satisfaction, life satisfaction, psychological strain, health symptoms). Fifth, the length of the SP-WFCS might limit its use in longitudinal and diary studies in which multiple constructs need to be examined across time (Stanton, Sinar, Balzer and Smith 2002). In such studies, researchers often measure constructs with the fewest items possible, as a way to reduce assessment time and increase response rates (Burisch 1984). Future studies should develop and validate an abbreviated measure of the SP-WFCS (see Matthews et al 2010). Finally, and consistently with the original version in English, the SP-WFCS only captures negative relationships (i.e., interference) between work and family domains. As argued by De Simone, Agus, Lasio, and Serri (2018), some recent studies have also demonstrated the positive effects (i.e., enrichment) of work-family interactions (also see McNall, Nicklin, and Masuda 2010 for a meta-analysis). Future studies should develop and validate a Spanish version of an instrument that adequately captures positive relationships between work and family (e.g., Work-Family Enrichment Scale; Carlson, Kacmar, Wayne, and Grzywacz 2006; for a Spanish version of the SWING, see Romeo et al. 2014).

\section{REFERENCES}

Allen, T. D., Herst, D. E., Bruck, C. S., \& Sutton, M. (2000). Consequences associated with work-to-family conflict: a review and agenda for future research. Journal of Occupational Health Psychology, 5(2), 278-308. https://doi.org/10.1037//1076$\underline{8998.5 .2 .278}$

Allen, T. D., \& Armstrong, J. (2006). Further examination of the link between workfamily conflict and physical health: The role of health-related behaviors. American Behavioral Scientist, $\quad 49(9), \quad 1204-1221$. https://doi.org/10.1177/0002764206286386 
Amstad, F. T., Meier, L. L., Fasel, U., Elfering, A., \& Semmer, N. K. (2011). A metaanalysis of work-family conflict and various outcomes with a special emphasis on cross-domain versus matching-domain relations. Journal of Occupational Health Psychology, 16(2), 151-169. https://doi.org/10.1037/a0022170

Arbuckle, J. L. (2014). Amos (Version 22.0) [Computer Program]. Chicago: IBM SPSS.

Bagozzi, R. P., \& Yi, Y. (1988). On the evaluation of structural equation models. Journal of the Academy of Marketing Science, 16, 74-94. https://doi.org/10.1177/009207038801600107

Bakker, A. B., Demerouti, D., \& Verbeke, W. (2004). Using the Job Demands-Resources model to predict burnout and performance. Human Resource Management, 43, 83-104. https://doi.org/10.1002/hrm.20004

Baltar, F., \& Brunet, I. (2012). Social research 2.0: virtual snowball sampling method using Facebook. Internet Research, 22(1), 57-74. https://doi.org/10.1108/10662241211199960

Berkman, L. F., Buxton, O., Ertel, K., \& Okechukwu, C. (2010). Managers' practices related to work-family balance predict employee cardiovascular risk and sleep duration in extended care settings. Journal of Occupational Health Psychology, 15(3), 316-329. https://doi.org/10.1037/a0019721

Bohen, H. H., \& Viveros-Long. (1981). Balancing jobs and family life: Do flexible work schedules really help? Philadelphia: Temple University Press.

Bollen, K. (1989). A new incremental fit index for general structural equation models. Sociological Methods and Research, 17(3), 303-316. https://doi.org/10.1177/0049124189017003004

Boyar, S. L., Carson, C. M., Mosley Jr, D. C., Maertz Jr, C. P., \& Pearson, A. W. (2006). Assessment of the validity of Netemeyer et al.'s (1996) WFC and FWC scales. 
International Journal of Conflict Management, 17(1), 34-44. https://doi.org/10.1108/10444060610734163

Burisch, M. (1984). Approaches to personality inventory construction: A comparison of merits. American Psychologist, 39, 214-227. https://doi.org/10.1037//0003$\underline{066 x .39 .3 .214}$

Brislin, R. W. (1980). Translation and content analysis of oral and written materials. In Triandis, H. C. \& Berry, J. W. (Eds.), Handbook of cross-cultural psychology. Boston: Allyn \& Bacon.

Bruck, C. S., Allen, T. D., \& Spector, P. E. (2002). The relation between work-family conflict and job satisfaction: A finer-grained analysis. Journal of Vocational Behavior, 60(3), 336-353. https://doi.org/10.1006/jvbe.2001.1836

Burke, R. J., \& Greenglass, E. R. (1999). Work-family conflict, spouse support, and nursing staff well-being during organizational restructuring. Journal of Occupational Health Psychology, 4(4), 327-336. https://doi.org/10.1037//1076$\underline{8998.4 .4 .327}$

Buss, D. M. (2009). An evolutionary formulation of person-situation interactions. Journal of Research in Personality, 43(2), 241-242. https://doi.org/10.1016/j.jrp.2008.12.019

Byrne, B. M. (2001). Structural equation modeling: Perspectives on the present and the future. International Journal of Testing, 1(3-4), 327-334. https://doi.org/10.1080/15305058.2001.9669479

Byron, K. (2005). A meta-analytic review of work-family conflict and its antecedents. Journal of Vocational Behavior, 67(2), 169-198. https://doi.org/10.1016/j.jvb.2004.08.009 
Carlson, D. S., Kacmar, K. M., \& Williams, L. J. (2000). Construction and initial validation of a multidimensional measure of work-family conflict. Journal of Vocational Behavior, 56(2), 249-276. https://doi.org/10.1006/jvbe.1999.1713

Carlson, D. S., Kacmar, K. M., Wayne, J. H., \& Grzywacz, J. G. (2006). Measuring the positive side of the work-family interface: Development and validation of a workfamily enrichment scale. Journal of Vocational Behavior, 68(1), 131-164. https://doi.org/10.1016/j.jvb.2005.02.002

Cheung, G., \& Rensvold, R. (2002). Evaluating goodness-of-fit indexes for testing measurement invariance. Structural Equation Modeling, 9(2), 233-255. https://doi.org/10.1207/s15328007sem0902_5

De Simone, S., Agus, M., Lasio, D., \& Serri, F. (2018). Development and validation of a measure of work-family interface. Revista de Psicología del Trabajo y de las Organizaciones, 34(3), 169-179. https://doi.org/10.5093/jwop2018a19

DeVellis, R. (2012). Scale development: Theory and applications. Los Angeles: Sage.

Dierdorff, E. C., \& Morgeson, F. P. (2013). Getting what the occupation gives: Exploring multilevel links between work design and occupational values. Personnel Psychology, 66(3), 687-721. https://doi.org/10.1111/peps.12023

Dormann, C., \& Zapf, D. (2004). Customer-related social stressors and burnout. Journal of Occupational Health Psychology, 9(1), 61-82. https://doi.org/10.1037/1076$\underline{8998.9 .1 .61}$

Eagle, B. W., Miles, E. W., \& Icenogle, M. L. (1997). Interrole conflicts and the permeability of work and family domains: Are there gender differences?. Journal of Vocational Behavior, 50(2), 168-184. https://doi.org/10.1006/jvbe.1996.1569 
Ford, M. T., Heinen, B. A., \& Langkamer, K. L. (2007). Work and family satisfaction and conflict: a meta-analysis of cross-domain relations. Journal of Applied Psychology, 92(1), 57-80. https://doi.org/10.1037/0021-9010.92.1.57

Fornell, C. \& Larcker, D. (1981). Evaluating structural equation models with unobservable variables and measurement error. Journal of Marketing Research, 18(1), 39-50. https://doi.org/10.1177/002224378101800104

Frone, M. R., Russell, M., \& Cooper, M. L. (1992). Antecedents and outcomes of workfamily conflict: Testing a model of the work-family interface. Journal of Applied Psychology, 77, 65-78. https://doi.org/10.1037//0021-9010.77.1.65

Frone, M. R., Russell, M., \& Cooper, M. L. (1997). Relation of work-family conflict to health outcomes: A four-year longitudinal study of employed parents. Journal of Occupational and Organizational Psychology, 70(4), 325-335. https://doi.org/10.1111/j.2044-8325.1997.tb00652.x

Frone, M. R. (2003). Work-family balance. In J. C. Quick \& L. E. Tetrick (Eds.), Handbook of occupational health psychology (pp. 143-162). Washington, DC: American Psychological Association.

Funder, D. (2008). Persons, Situations, and Person-situation Interactions. In L. Pervin, O. John, \& R. Robins (Eds.), Handbook of Personality Research (3rd Ed.). New York: Guilford.

Funder, D., Guillaume, E., Kumagai, S, Kawamoto, S., \& Sato, T. (2012). The Personsituation Debate and the Assessment of Situations. The Japanese Journal of Personality, 21(1), 1-11. https://doi.org/10.2132/personality.21.1

Gaffey, A. R., \& Rottinghaus, P. J. (2009). The factor structure of the work-family conflict multidimensional scale: Exploring the expectations of college students. 
Journal of Career Assessment, 17(4), 495-506. https://doi.org/10.1177/1069072709340662

Germeys, L., \& De Gieter, S. (2017). Clarifying the dynamic interrelation of conflicts between the work and home domain and counterproductive work behaviour. European Journal of Work and Organizational Psychology, 26, 457-467. https://doi.org/10.1080/1359432X.2017.1314266

Geurts, S. A. E., Toon, T. W., Kompier, M. A. J., Dikkers, J. S. E., Van Hooff, M. L. M., \& Kinnunen, U. M. (2005). Work-home interaction from a work psychological perspective: Development and validation of a new questionnaire, the SWING. Work \& Stress, 19, 319-339. https://doi.org/10.1080/02678370500410208

Geurts, S. A., Kompier, M. A., Roxburgh, S., \& Houtman, I. L. (2003). Does work-home interference mediate the relationship between workload and well-being?. Journal of Vocational Behavior, 63(3), 532-559. https://doi.org/10.1016/s0001$\underline{8791(02) 00025-8}$

Goff, S. J., Mount, M. K., \& Jamison, R. L. (1990). Employer supported child care, work/family conflict, and absenteeism: A field study. Personnel Psychology, 43(4), 793-809. https://doi.org/10.1111/j.1744-6570.1990.tb00683.x

Greenhaus, J. H., \& Beutell, N. J. (1985). Sources of conflict between work and family roles. Academy of Management Review, 10, 76-88. https://doi.org/10.5465/amr.1985.4277352

Gutek, B. A., Searle, S., \& Klepa, L. (1991). Rational versus gender role explanations for work-family conflict. Journal of Applied Psychology, 76, 560-568. https://doi.org/10.1037//0021-9010.76.4.560 
Haines III, V. Y., Harvey, S., Durand, P., \& Marchand, A. (2013). Core Self-Evaluations, Work-Family Conflict, and Burnout. Journal of Marriage and Family, 75(3), 778-793. https://doi.org/10.1111/jomf.12026

Hair, J., Black, W., Babin, B. \& Anderson, R. (2010). Multivariate data analysis: A global perspective. New Jersey: Pearson Prentice Hall.

Hambleton, R. K., Merenda, P. F., \& Spielberger, C. D. (2006). Adapting educational and psychological tests for cross-cultural assessment. Mahwah, NJ: Lawrence Erlbaum.

Hirschfeld, G., \& Von Brachel, R. (2014). Multiple-Group confirmatory factor analysis in R-A tutorial in measurement invariance with continuous and ordinal indicators. Practical Assessment, Research \& Evaluation, 19(7), 1-11.

Hogan, R. (2009). Much ado about nothing: The person-situation debate. Journal of Research in Personality, 43(2), 249. https://doi.org/10.1016/j.jrp.2009.01.022

Hu, L. T., \& Bentler, P. M. (1999). Cutoff criteria for fit indexes in covariance structure analysis: Conventional criteria versus new alternatives. Structural Equation Modeling: $\quad a \quad$ Multidisciplinary $\quad$ Journal, $\quad 6(1), \quad 1-55$. https://doi.org/10.1080/10705519909540118

Hubley, A. (2014). Discriminant validity. In A. Michalos (Ed.), Encyclopedia of quality of life and well-being research (pp. 1664-1667). Dordrecht: Springer.

Hugman, R., Pittaway, E., \& Bartolomei, L. (2011). When 'do no harm' is not enough: The ethics of research with refugees and other vulnerable groups. The British Journal of Social Work, 41(7), 1271-1287. https://doi.org/10.1093/bjsw/bcr013

Humphrey, S. E., Nahrgang, J. D., \& Morgeson, F. P. (2007). Integrating motivational, social, and contextual work design features: a meta-analytic summary and 
theoretical extension of the work design literature. Journal of Applied Psychology, 92(5), 1332-1356. https://doi.org/10.1037/0021-9010.92.5.1332

International Test Commission (2017). The ITC Guidelines for Translating and Adapting Tests (Second edition). Retrieved from www.InTestCom.org

Judge, T. A., Locke, E. A., \& Durham, C. C. (1997). The dispositional causes of job satisfaction: A core evaluations approach. Research in Organizational Behavior, 19(1), 151-188.

Judge, T. A., Locke, E. A., Durham, C. C., \& Kluger, A. N. (1998). Dispositional effects on job and life satisfaction: The role of core evaluations. Journal of Applied Psychology, 83(1), 17-34. https://doi.org/10.1037//0021-9010.83.1.17

Judge, T. A., Bono, J. E., \& Locke, E. A. (2000). Personality and job satisfaction: The mediating role of job characteristics. Journal of Applied Psychology, 85(2), 237249. https://doi.org/10.1037//0021-9010.85.2.237

Judge, T. A., Erez, A., Bono, J. E., \& Thoresen, C. J. (2003). The core self-evaluations scale: Development of a measure. Personnel Psychology, 56(2), 303-331. https://doi.org/10.1111/j.1744-6570.2003.tb00152.x

Kammeyer-Mueller, J. D., Judge, T. A., \& Scott, B. A. (2009). The role of core selfevaluations in the coping process. Journal of Applied Psychology, 94(1), 177-195. https://doi.org/10.1037/a0013214

Kline, R. B. (2010). Principles and practice of structural equation modeling. New York: Guilford.

Kreiner, G. (2006). Consequences of work home segmentation or integration: A person environment fit perspective. Journal of Organizational Behavior, 27(4), 485-507. https://doi.org/10.1002/job.386 
Lazzaro-Salazar, M. (2018). Researchers as brokers: Reflections from a study of migrant physicians in Chile. The Social Science Journal. Advance online publication. https://doi.org/10.1016/j.soscij.2018.09.006

McNall, L. A., Nicklin, J. M., \& Masuda, A. D. (2010). A meta-analytic review of the consequences associated with work-family enrichment. Journal of Business and Psychology, 25(3), 381-396. https://doi.org/10.1007/s10869-009-9141-1

Marais, C., Mostert, K., Geurts, S., \& Taris, T. (2009). The psychometric properties of a translated version of the Survey Work-Home Interaction - Nijmegen (SWING) instrument. SA Journal of Psychology, 39(2), 202-219. https://doi.org/10.1177/008124630903900206

Maslach, C., Jackson, S. E., \& Leiter, M. P. (1996). Maslach burnout inventory manual (Vol. 4). Palo Alto, CA: Consulting Psychologists Press.

Matthews, R. A., Kath, L. M., \& Barnes-Farrell, J. L. (2010). A short, valid, predictive measure of work-family conflict: Item selection and scale validation. Journal of Occupational Health Psychology, 15(1), 75-90. https://doi.org/10.1037/a0017443

Meijman, T. F., \& Mulder, G. (1998). Psychological aspects of workload. In P. J. Drenth, H. Thierry, \& C. J. de Wolff (Eds.), Handbook of work and organizational psychology (pp. 5-33). Hove, UK: Psychology Press.

Michel, J. S., Kotrba, L. M., Mitchelson, J. K., Clark, M. A., \& Baltes, B. B. (2011). Antecedents of work-family conflict: A meta-analytic review. Journal of Organizational Behavior, 32(5), 689-725. https://doi.org/10.1002/job.695

Moncada, S., \& Llorens, C. (2004). Evaluación y acción preventiva ante el riesgo psicosocial: El método istas-21 (COPSOQ). Gestión Práctica de Riesgos Laborales, 5, 12-20. 
Mortazavi, S., Pedhiwala, N., Shafiro, M., \& Hammer, L. (2009). Work-family conflict related to culture and gender. Community, Work \& Family, 12(2), 251-273. https://doi.org/10.1080/13668800902779023

Muñiz, J., Elosua, P., \& Hambleton, R. K. (2013). Directrices para la traducción y adaptación de los tests: segunda edición. Psicothema, 25(2), 151-157.

Netemeyer, R. G., Boles, J. S., \& McMurrian, R. (1996). Development and validation of work-family conflict and family-work conflict scales. Journal of Applied Psychology, 81, 400-410. https://doi.org/10.1037/0021-9010.81.4.400

Netemeyer, R. G., Brashear-Alejandro, T., \& Boles, J. S. (2004). A cross-national model of job-related outcomes of work role and family role variables: A retail sales context. Journal of the Academy of marketing Science, 32(1), 49-60. https://doi.org/10.1177/0092070303259128

Nohe, C., Meier, L. L., Sonntag, K., \& Michel, A. (2015). The chicken or the egg? A meta-analysis of panel studies of the relationship between work-family conflict and strain. Journal of Applied Psychology, 100(2), 522-536. https://doi.org/10.1037/a0038012

Nunnally, J. C. (1978). Psychometric theory. New York: McGraw-Hill.

O’Donnell, E., Berkman, L. F., Kelly, E., Hammer, L., Marden, J., \& Buxton, O. M. (2019). Cardiometabolic risks associated with work-to-family conflict: findings from the Work Family Health Network. Community, Work \& Family, 22(2), 203228. https://doi.org/10.1080/13668803.2018.1457003

Peeters, M. C. W., de Jonge, J., Janssen, P. P. M., \& van der Linden, S. (2004). Workhome interference, job stressors, and employee health in a longitudinal perspective. International Journal of Stress Management, 11, 305-322. https://doi.org/10.1037/1072-5245.11.4.305 
Peeters, M. C., Montgomery, A. J., Bakker, A. B., \& Schaufeli, W. B. (2005). Balancing work and home: how job and home demands are related to burnout. International Journal of Stress Management, 12(1), 43-61. https://doi.org/10.1037/1072$\underline{5245.12 .1 .43}$

Perry-Jenkins, M., \& Wadsworth, S. M. (2017). Work and family research and theory: review and analysis from an ecological perspective. Journal of Family Theory \& Review, 9(2), 219-237. https://doi.org/10.1111/jftr.12188

Pezirkianidis, C., Stalikas, A., Lakioti, A., \& Yotsidi, V. (2019). Validating a multidimensional measure of wellbeing in Greece: Translation, factor structure, and measurement invariance of the PERMA Profiler. Current Psychology, 1-18. https://doi.org/10.1007/s12144-019-00236-7

Podsakoff, P. M., MacKenzie, S. B., Lee, J. Y., \& Podsakoff, N. P. (2003). Common method biases in behavioral research: A critical review of the literature and recommended remedies. Journal of Applied Psychology, 88(5), 879-903. https://doi.org/10.1037/0021-9010.88.5.879

Post, C., DiTomaso, N., Farris, G. F., \& Cordero, R. (2009). Work-family conflict and turnover intentions among scientists and engineers working in R\&D. Journal of Business and Psychology, 24(1), 19-32. https://doi.org/10.1007/s10869-0099089-1

Pujol-Cols, L. J., \& Dabos, G. E. (2017, October). Factores disposicionales y situacionales en el trabajo: validación de escalas y análisis de sus influencias sobre la Satisfacción Laboral. In K. Collins (Conference Chair), Leadership and Management of Human Capital. 52nd Annual Assembly CLADEA 2017. Riverside, United States of America. 
Pujol-Cols, L., \& Arraigada, M. (2017). Propiedades psicométricas del Cuestionario de Riesgos Psicosociales Copsoq-Istas 21 y aplicación en docentes universitarios argentinos. Cuadernos de Administración, 30(55), 97-125. https://doi.org/10.11144/javeriana.cao30-55.ppcr

Pujol-Cols, L., \& Lazzaro-Salazar, M. (2018). Psychosocial risks and job satisfaction in Argentinian scholars: Exploring the moderating role of work engagement. Journal of Work and Organizational Psychology, 34(3), 145-156. https://doi.org/10.5093/jwop2018a17

Pujol-Cols, L. J, \& Dabos, G. E. (2019). Dispositional and situational factors at work: A validation of scales and examination of effects on job satisfaction. Academia: Revista Latinoamericana de Administración. Advance online publication. https://doi.org/10.1108/ARLA-12-2017-0355

Pujol-Cols, L. (2019). Core Self-Evaluations, Perceived Job Characteristics and Job Satisfaction: Evidence from Two Independent Samples of Highly Skilled Argentinian Workers. Revista Colombiana de Psicología, 28(1), 131-146. https://doi.org/10.15446/rcp.v28n1.70420

Pujol-Cols, L., \& Lazzaro-Salazar, M. (in press). Psychological demands and health: An examination of the role of core self-evaluations in the stress-coping process. Psychological Studies.

Reis, H. T. (2008). Reinvigorating the concept of situation in social psychology. Personality and Social Psychology Review, 12(4), 311-329. https://doi.org/10.1177/1088868308321721

Rodríguez, M. C., \& Dabos, G. E. (2017). Gestión individual del equilibrio entre el trabajo y la vida personal: revisión e integración de la literatura. Revista Facultad 
de Ciencias Económicas: Investigación y Reflexión, 25(1), 219-242. https://doi.org/10.18359/rfce.1055

Rodríguez, M. C., Dabos, G. E., \& Rivero, A. G. (2018). Implementación de políticas de conciliación trabajo-vida en pequeñas y medianas empresas: un estudio de casos múltiples en la industria del software. Estudios Gerenciales, 34(147), 172-189. https://doi.org/10.18046/j.estger.2018.147.2592

Romeo, M., Berger, R., Yepes-Baldó, M., \& Ramos, B. (2014). Adaptation and validation of the Spanish Version of the "Survey Work-Home Interaction-NijmeGen" (SWING) to Spanish speaking countries. Anales de Psicología, 30(1), 287-293. https://doi.org/10.6018/analesps.30.1.148291

Shaffer, M. A., Harrison, D. A., Gilley, K. M., \& Luk, D. M. (2001). Struggling for balance amid turbulence on international assignments: Work-family conflict, support and commitment. Journal of Management, 27(1), 99-121. https://doi.org/10.1177/014920630102700106

Shaffer, M. A., Joplin, J. R., \& Hsu, Y. S. (2011). Expanding the boundaries of workfamily research: A review and agenda for future research. International Journal of Cross Cultural Management, 11(2), 221-268. https://doi.org/10.1177/1470595811398800

Shimada, K., Shimazu, A., Geurts, S. A., \& Kawakami, N. (2019). Reliability and validity of the Japanese version of the Survey Work-Home Interaction-NijmeGen, the SWING (SWING-J). Community, Work \& Family, 22(3), 267-283. https://doi.org/10.1080/13668803.2018.1471588

Shockley, K. M., \& Singla, N. (2011). Reconsidering work-family interactions and satisfaction: A meta-analysis. Journal of Management, 37(3), 861-886. https://doi.org/10.1177/0149206310394864 
Soper, D.S. (2019). A-priori Sample Size Calculator for Structural Equation Models [Software]. Available from http://www.danielsoper.com/statcalc

Spector, P. E., Allen, T. D., Poelmans, S., Lapierre, L. M., Cooper, C. L., O’Driscoll, M. P., et al. (2007). Cross-national differences in relationships of work demands, job satisfaction, and turnover intentions with work-family conflict. Personnel Psychology, 60, 805-835. https://doi.org/10.1111/j.1744-6570.2007.00092.x

Srivastava, A., Locke, E. A., Judge, T. A., \& Adams, J. W. (2010). Core self-evaluations as causes of satisfaction: The mediating role of seeking task complexity. Journal of Vocational $\quad$ Behavior, $\quad$ 255-265. https://doi.org/10.1016/j.jvb.2010.04.008

Stanton, J. M., Sinar, E. F., Balzer, W. K., \& Smith, P. C. (2002). Issues and strategies for reducing the length of self-report scales. Personnel Psychology, 55(1), 167194. https://doi.org/10.1111/j.1744-6570.2002.tb00108.x

Thompson, E. R., \& Phua, F. T. (2012). A brief index of affective job satisfaction. Group \& Organization $\quad$ Management, $\quad 37(3), \quad$ 275-307. https://doi.org/10.1177/1059601111434201

Van Steenbergen, E. F., Ellemers, N., \& Mooijaart, A. (2007). How work and family can facilitate each other: Distinct types of work-family facilitation and outcomes for women and men. Journal of Occupational Health Psychology, 12(3), 279-300. https://doi.org/10.1037/1076-8998.12.3.279

Vieira, J. M., Lopez, F. G., \& Matos, P. M. (2014). Further validation of work-family conflict and work-family enrichment scales among Portuguese working parents. Journal of Career Assessment, 22(2), 329-344. https://doi.org/10.1177/1069072713493987 
Watai, I., Nishikido, N., \& Murashima, S. (2006). Development of a Japanese Version of the Work-Family Conflict Scale (WFCS), and examination of its validity and reliability. Journal of Occupational Health, 48(3), 71-81. https://doi.org/10.1539/sangyoeisei.48.71

Williams, L. J., Bozdogan, H., \& Aiman-Smith, L. (1996). Inference problems with equivalent models. In G. A. Marcoulides \& R. E. Schumacker (Eds.), Advanced structural equations modeling. Mahwah, NJ: Erlbaum

Witt, L. A., \& Carlson, D. S. (2006). The work-family interface and job performance: moderating effects of conscientiousness and perceived organizational support. Journal of Occupational Health Psychology, 11(4), 343-357. https://doi.org/10.1037/1076-8998.11.4.343

Wu, C. H., \& Griffin, M. A. (2012). Longitudinal relationships between core selfevaluations and job satisfaction. Journal of Applied Psychology, 97(2), 331-342. https://doi.org/10.1037/a0025673

Zhang, J., \& Liu, Y. (2011). Antecedents of work-family conflict: Review and prospect. International Journal of Business and Management, 6(1), 89-104. https://doi.org/10.12804/apl32.1.2014.09

Zhang, M., Griffeth, R. W., \& Fried, D. D. (2012). Work-family conflict and individual consequences. Journal of Managerial Psychology, 27(7), 696-713. https://doi.org/10.1108/02683941211259520 


\section{APPENDIX \\ The Spanish Work-Family Conflict Scale (SP-WFCS)}

1. Mi trabajo me impide participar en las actividades de mi familia más de lo que querría

2. El tiempo que debo dedicar a mi trabajo me impide participar en el mismo grado en las actividades y responsabilidades del hogar

3. Tengo que perderme algunas actividades familiares como resultado del tiempo que debo dedicar a las responsabilidades de mi trabajo

4. El tiempo que dedico a las responsabilidades familiares a menudo interfiere con las responsabilidades de mi trabajo

5. El tiempo que paso con mi familia a menudo impide que desarrolle actividades laborales que podrían beneficiar mi carrera

6. Tengo que perderme actividades laborales debido al tiempo que debo dedicarle a las responsabilidades y actividades familiares

7. A menudo, cuando regreso del trabajo me siento demasiado exhausto como para participar en las actividades/responsabilidades familiares

8. Muchas veces, cuando regreso del trabajo me siento tan emocionalmente agotado que eso me impide contribuir en las actividades familiares

9. Como resultado de las presiones en el trabajo, algunas veces, cuando regreso a mi hogar me siento demasiado estresado para hacer las cosas que disfruto

10. Debido al estrés del hogar, estoy frecuentemente preocupado por asuntos familiares en el trabajo

11. Dado que a menudo estoy estresado por responsabilidades familiares, me cuesta concentrarme en mi trabajo 
12. La tensión y ansiedad de mi vida familiar frecuentemente debilita mi capacidad para hacer mi trabajo

13. La forma en la que resuelvo los problemas en mi trabajo no es efectiva para resolver los problemas relacionados con mi familia

14. El comportamiento que es efectivo y necesario para mí en el trabajo sería contraproducente si lo empleara en mi hogar

15. El comportamiento que me hace efectivo en mi trabajo no me ayuda a ser un mejor padre o pareja en el hogar

16. El tipo de comportamiento que me funciona en el hogar no parece ser efectivo en mi trabajo

17. El comportamiento que es necesario y efectivo para mí en el hogar sería contraproducente si lo empleara en mi trabajo

18. Las formas en las que resuelvo los problemas en mi hogar no parecen ser útiles para resolver problemas en mi trabajo 


\section{TABLES}

Table 1. Fit statistics from confirmatory factor analysis

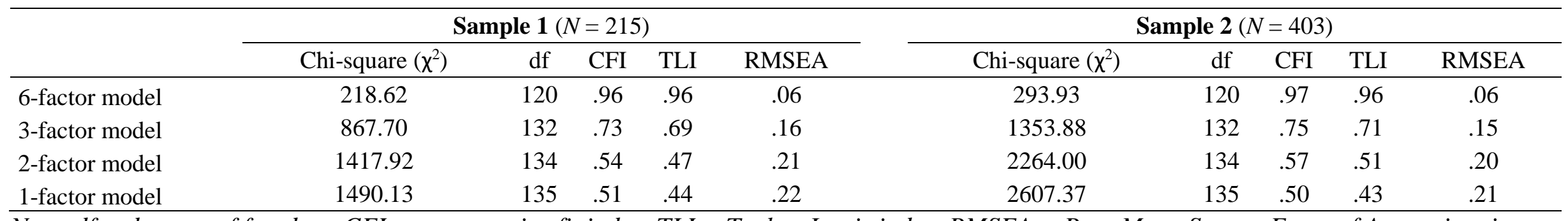

Note. $d f=$ degrees of freedom, $C F I=$ comparative fit index, $T L I=$ Tucker-Lewis index, RMSEA = Root Mean Square Error of Approximation 
Table 2. Means, standard deviations and internal consistency levels

\begin{tabular}{lcccccccc}
\hline \multirow{2}{*}{ Dimension } & \multicolumn{3}{c}{ Sample $1(N=215)$} & & \multicolumn{3}{c}{ Sample $2(N=403)$} \\
\cline { 2 - 3 } & $\mathrm{M}$ & $\mathrm{SD}$ & $\alpha$ & & $\mathrm{M}$ & $\mathrm{SD}$ & $\alpha$ \\
\hline Time-based work interference with family & 2.47 & 1.09 & .91 & & 3.16 & 1.10 & .90 \\
Time-based family interference with work & 2.16 & .94 & .87 & & 2.74 & 1.05 & .84 \\
Strain-based work interference with family & 2.49 & 1.00 & .87 & & 3.21 & 1.16 & .88 \\
Strain-based family interference with work & 2.16 & .92 & .89 & & 2.24 & .93 & .84 \\
Behavior-based work interference with family & 2.66 & .97 & .80 & & 2.82 & 1.03 & .85 \\
Behavior-based family interference with work & 2.69 & 1.02 & .92 & & 2.82 & 1.07 & .91 \\
\hline
\end{tabular}

Note. $M=$ Mean, $S D=$ Standard deviation, $\alpha=$ Cronbach's alpha coefficient. 
Table 3. Convergent validity of the SP-WFCS

\begin{tabular}{|c|c|c|c|c|c|c|c|}
\hline \multirow{2}{*}{ Factor } & \multirow{2}{*}{ Item } & \multicolumn{3}{|c|}{ Sample $1(N=215)$} & \multicolumn{3}{|c|}{ Sample $2(N=403)$} \\
\hline & & SFL & AVE & $\mathrm{CR}$ & SFL & AVE & $\mathrm{CR}$ \\
\hline \multirow{3}{*}{$\begin{array}{l}\text { Time-based work } \\
\text { interference with } \\
\text { family }\end{array}$} & 1 & .91 & & & .87 & & \\
\hline & 2 & .91 & .78 & .91 & .92 & .75 & .90 \\
\hline & 3 & .82 & & & .80 & & \\
\hline \multirow{3}{*}{$\begin{array}{l}\text { Time-based family } \\
\text { interference with } \\
\text { work }\end{array}$} & 4 & .79 & & & .74 & & \\
\hline & 5 & .84 & .71 & .88 & .89 & .66 & .85 \\
\hline & 6 & .90 & & & .80 & & \\
\hline \multirow{3}{*}{$\begin{array}{l}\text { Strain-based work } \\
\text { interference with } \\
\text { family }\end{array}$} & 7 & .84 & & & .89 & & \\
\hline & 8 & .90 & .70 & .90 & .87 & .73 & .89 \\
\hline & 9 & .76 & & & .80 & & \\
\hline \multirow{3}{*}{$\begin{array}{l}\text { Strain-based family } \\
\text { interference with } \\
\text { work }\end{array}$} & 10 & .77 & & & .64 & & \\
\hline & 11 & .92 & .74 & .89 & .89 & .67 & .86 \\
\hline & 12 & .88 & & & .90 & & \\
\hline \multirow{3}{*}{$\begin{array}{l}\text { Behavior-based work } \\
\text { interference with } \\
\text { family }\end{array}$} & 13 & .66 & & & .69 & & \\
\hline & 14 & .83 & .59 & .81 & .87 & .66 & .85 \\
\hline & 15 & .80 & & & .87 & & \\
\hline \multirow{3}{*}{$\begin{array}{l}\text { Behavior-based } \\
\text { family interference } \\
\text { with work }\end{array}$} & 16 & .91 & & & .90 & & \\
\hline & 17 & .91 & .80 & .92 & .88 & .77 & .91 \\
\hline & 18 & .86 & & & .85 & & \\
\hline
\end{tabular}


Table 4. Discriminant validity of the SP-WFCS

\begin{tabular}{lcccccccc}
\hline & \multicolumn{4}{c}{ Correlations } & \multicolumn{3}{c}{ AVE } \\
\cline { 2 - 7 } & 1 & 2 & 3 & 4 & 5 & 6 & Sample 1 & Sample 2 \\
\hline 1. Time-based work interference with family & - & $.37[.14]$ & $.66[.43]$ & $.31[.10]$ & $.38[.14]$ & $.36[.13]$ & .78 & .75 \\
2. Time-based family interference with work & $.44[.19]$ & - & $.37[.14]$ & $.37[.14]$ & $.27[.07]$ & $.26[.07]$ & .71 & .66 \\
3. Strain-based work interference with family & $.55[.30]$ & $.41[.17]$ & - & $.42[.18]$ & $.41[.17]$ & $.39[.15]$ & .70 & .73 \\
4. Strain-based family interference with work & $.24[.06]$ & $.41[.17]$ & $.42[.18]$ & - & $.42[.18]$ & $.33[.11]$ & .74 & .67 \\
5. Behavior-based work interference with family & $.44[.19]$ & $.38[.14]$ & $.46[.21]$ & $.46[.21]$ & - & $.72[.52]$ & .59 & .66 \\
6. Behavior-based family interference with work & $.48[.23]$ & $.29[.08]$ & $.40[.16]$ & $.34[.12]$ & $.77[.59]$ & - & .80 & .77 \\
\hline
\end{tabular}

Note. AVE = average variance extracted. All correlations are statistically significant at the $p<.001$ level. Correlations and shared variance estimates for sample 1 are reported bellow the principal diagonal. Correlations and shared variance estimates for sample 2 are reported above the principal diagonal. Shared variance estimates are reported in brackets. 
Table 5. Test of Measurement Invariance

\begin{tabular}{|c|c|c|c|c|c|c|c|c|c|c|}
\hline Models & $\chi^{2}$ & $d f$ & $\Delta \chi^{2}$ & $\Delta d f$ & CFI & $\Delta \mathrm{CFI}$ & TLI & $\Delta \mathrm{TLI}$ & RMSEA & $\triangle$ RMSEA \\
\hline Model 1 - No constraints (baseline model) & $512.64 * *$ & 240 & & & .965 & & .955 & & .043 & \\
\hline Model 2 - Factor loadings invariant & $525.49 * *$ & 252 & 12.85 & 12 & .964 & .001 & .957 & .002 & .042 & .001 \\
\hline $\begin{array}{l}\text { Model } 3 \text { - Factor loadings \& factor correlations } \\
\text { invariant }\end{array}$ & $562.58 * *$ & 273 & $49.94 *$ & 33 & .962 & .002 & .958 & .001 & .041 & .001 \\
\hline $\begin{array}{l}\text { Model } 4 \text { - Factor loadings, factor correlations, \& error } \\
\text { variances invariant }\end{array}$ & $630.55^{* *}$ & 291 & $117.92 * *$ & 51 & .956 & .006 & .954 & .004 & .044 & .003 \\
\hline
\end{tabular}




\section{Table 6. Test of Gender Invariance}

\begin{tabular}{|c|c|c|c|c|c|c|c|c|c|c|}
\hline Models & $\chi^{2}$ & $d f$ & $\Delta \chi^{2}$ & $\Delta d f$ & CFI & $\Delta \mathrm{CFI}$ & TLI & $\Delta \mathrm{TLI}$ & RMSEA & $\triangle \mathrm{RMSEA}$ \\
\hline Model 1 - No constraints (baseline model) & $488.47 * *$ & 240 & & & .969 & & .960 & & .041 & \\
\hline Model 2 - Factor loadings invariant & $503.19 * *$ & 252 & 14.72 & 12 & .968 & .001 & .961 & .001 & .040 & .001 \\
\hline $\begin{array}{l}\text { Model } 3 \text { - Factor loadings \& factor correlations } \\
\text { invariant }\end{array}$ & $550.96^{* *}$ & 273 & $62.49 * *$ & 33 & .965 & .003 & .961 & .000 & .041 & .001 \\
\hline $\begin{array}{l}\text { Model } 4 \text { - Factor loadings, factor correlations, \& error } \\
\text { variances invariant }\end{array}$ & $612.61 * *$ & 291 & $124.14 * *$ & 51 & .959 & .006 & .957 & .004 & .042 & .001 \\
\hline
\end{tabular}


Table 7. Antecedents and outcomes of work-family conflict

\begin{tabular}{|c|c|c|c|c|c|c|c|c|c|c|c|c|}
\hline \multirow[t]{2}{*}{ Variables } & \multicolumn{2}{|c|}{$\begin{array}{l}\text { Time-based work } \\
\text { interference with } \\
\text { family }\end{array}$} & \multicolumn{2}{|c|}{$\begin{array}{c}\text { Time-based } \\
\text { family } \\
\text { interference with } \\
\text { work } \\
\end{array}$} & \multicolumn{2}{|c|}{$\begin{array}{c}\text { Strain-based } \\
\text { work } \\
\text { interference with } \\
\text { family } \\
\end{array}$} & \multicolumn{2}{|c|}{$\begin{array}{c}\text { Strain-based } \\
\text { family } \\
\text { interference with } \\
\text { work } \\
\end{array}$} & \multicolumn{2}{|c|}{$\begin{array}{c}\text { Behavior-based } \\
\text { work } \\
\text { interference with } \\
\text { family } \\
\end{array}$} & \multicolumn{2}{|c|}{$\begin{array}{l}\text { Behavior-based } \\
\text { family } \\
\text { interference with } \\
\text { work }\end{array}$} \\
\hline & $\mathrm{S} 1$ & $\mathrm{~S} 2$ & $\mathrm{~S} 1$ & $\mathrm{~S} 2$ & $\mathrm{~S} 1$ & $\mathrm{~S} 2$ & $\mathrm{~S} 1$ & $\mathrm{~S} 2$ & S1 & $\mathrm{S} 2$ & $\mathrm{~S} 1$ & $\mathrm{~S} 2$ \\
\hline \multicolumn{13}{|l|}{ Antecedents } \\
\hline CSEs & $-.24 * * *$ & $-.30 * * *$ & $-.37 * * *$ & $-.23 * * *$ & $-.38 * * *$ & $-.37 * * *$ & $-.40 * * *$ & $-.27 * * *$ & $-.34 * * *$ & $-.24 * * *$ & $-.25 * * *$ & $-.23 * * *$ \\
\hline Quantitative demands & $.36 * * *$ & $.44 * * *$ & $.26 * * *$ & $.20 * * *$ & $.38 * * *$ & $.44 * * *$ & .11 n.s. & $.17 * * *$ & $.19 * * *$ & $.21 * * *$ & $.14 * *$ & $.19 * * *$ \\
\hline Emotional demands & $.33 * * *$ & $.51 * * *$ & $.27 * * *$ & $.26 * * *$ & $.41 * * *$ & $.64 * * *$ & .10 n.s. & $.32 * * *$ & $.25 * * *$ & $.39 * * *$ & $.22 * * *$ & $.42 * * *$ \\
\hline \multicolumn{13}{|l|}{ Outcomes } \\
\hline Affective job satisfaction & $-.11 *$ & & $-.16^{* *}$ & & $-.20 * * *$ & & $-.14 * *$ & & $-.23 * * *$ & & $-.21 * * *$ & \\
\hline Burnout & - & & - & & - & & - & & - & & - & \\
\hline Emotional exhaustion & - & $.54 * * *$ & - & $.28 * * *$ & - & $.68 * * *$ & - & $.30 * * *$ & - & $.30 * * *$ & - & $.34 * * *$ \\
\hline Depersonalization & - & $.29 * * *$ & - & $.17 * * *$ & - & $.33 * * *$ & - & $.25 * * *$ & - & $.25 * * *$ & - & $.29 * * *$ \\
\hline Professional accomplishment & - & -.07 n.s. & - & -.08 n.s. & - & $-.14 * * *$ & - & $-.11 * *$ & - & $-.16 * * *$ & - & $-.19 * * *$ \\
\hline
\end{tabular}

Note. S1 = Sample 1, S2 = Sample 2, CSEs = Core Self-Evaluations. $* p<.10, * * p<.05, * * * p<.01$, n.s. = non-significant. 
Figure 1. Confirmatory factor analysis results for the SP-WFCS

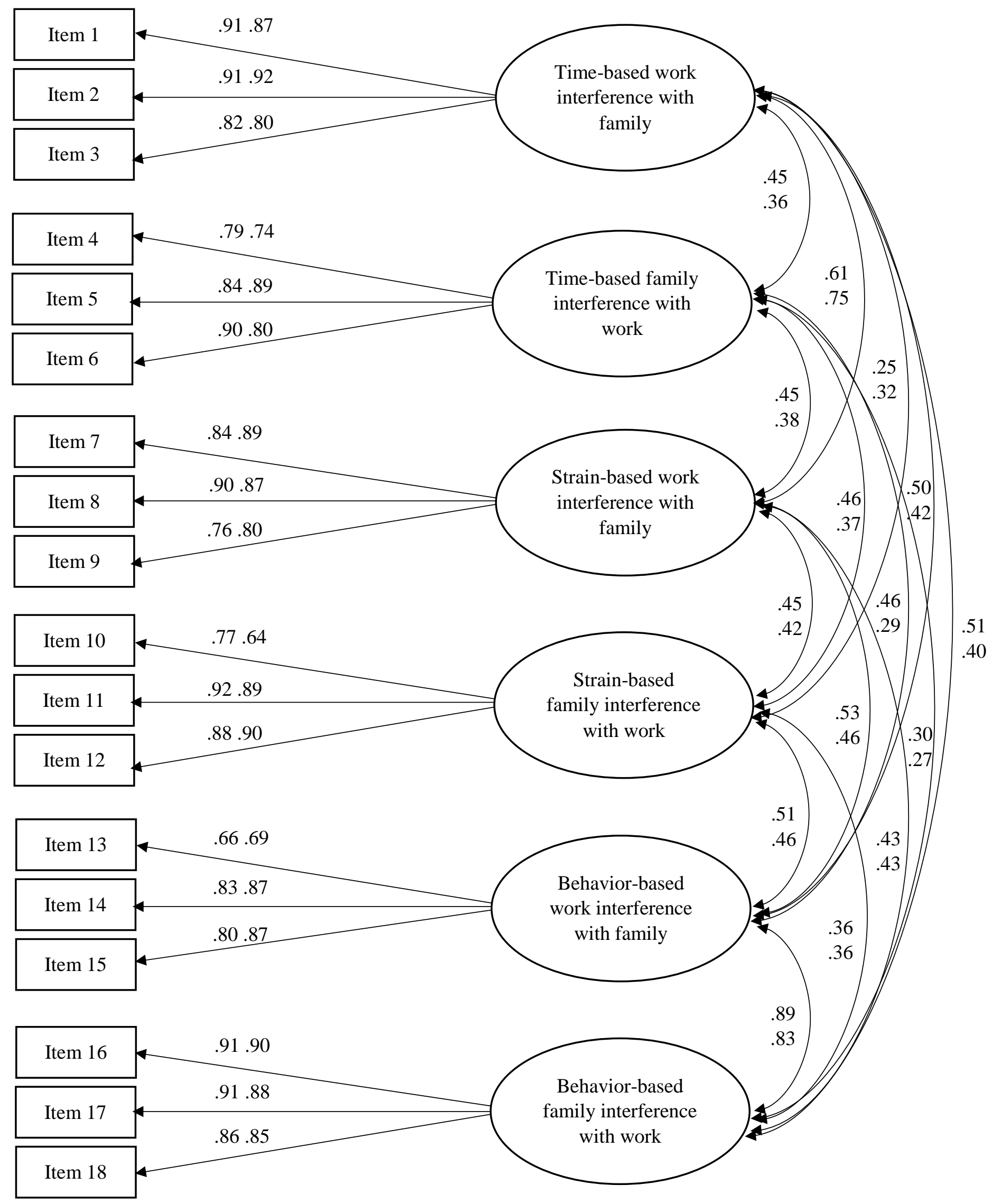

Note. All standardized factor loadings and covariances are statistically significant at the $p<.01$ level. Standardized factor loadings for sample 1 are reported on the first column. Standardized factor loadings for sample 2 are reported on the second column. Covariances for sample 1 are reported on the first row. Covariances for sample 2 are reported on the second row. 